\title{
Effect of organic and inorganic sources of nutrients on availability of major and micronutrients at different growth stages of groundnut (Arachis hypogaea L.) in two texturally different soils
}

\section{P. KAMALAKANNAN AND M. RAVICHANDRAN}

Received : 01.10.2014; Revised : 14.10.2014; Accepted : 01.11.2014

\section{MEMBERS OF RESEARCH FORUM:}

Corresponding author :

P. KAMALAKANNAN, Department of

Soil Science and Agricultural

Chemistry, Faculty of Agriculture,

Annamalai University,

Annamalainagar, CHIDAMBARAM

(T.N.) INDIA

Email:kamal_soil@yahoo.co.in

\section{Co-authors :}

M. RAVICHANDRAN, Department of Soil Science and Agricultural Chemistry, Faculty of Agriculture, Annamalai University,

Annamalainagar, CHIDAMBARAM (T.N.) INDIA

\section{Summary}

Field experiments were carried out in a farmers field at Chinnathanakuppam and Ayeekuppam villages, Cuddalore district during December, 2009 and March, 2010 to evaluate suitable organic and inorganic sources of nutrients on availability of major and micronutrients at different growth stages of groundnut. The experimental site at Chinnathanakuppam village belongs to Vadalapakkam series (Typic Rhodustalf) with sandy clay loam texture having $\mathrm{pH}-7.8$ and EC- $0.36 \mathrm{dSm}^{-1}$. The soil was low in organic carbon $\left(3.4 \mathrm{~g} \mathrm{~kg}^{-1}\right)$, medium is in alkaline $\mathrm{KMnO}_{4}-\mathrm{N}\left(285 \mathrm{~kg} \mathrm{ha}^{-1}\right)$, low in olsen-P $\left(11.0 \mathrm{~kg} \mathrm{ha}^{-1}\right)$ and medium in $\mathrm{NH}_{4} \mathrm{OAC}-\mathrm{K} 190 \mathrm{~kg} \mathrm{ha}^{-1}$. The experimental soil at Ayeekuppam village belongs to Vadupudupet series (Typic Haplustalf) with loamy sand in texture, having a $\mathrm{pH}-8.1$ and EC- $0.41 \mathrm{dSm}^{-1}$. The soil was low in $\mathrm{OC}\left(2.8 \mathrm{~g} \mathrm{ha}^{-1}\right)$, low in available nitrogen $(230 \mathrm{~kg}$ $\left.\mathrm{ha}^{-1}\right)$ and $\mathrm{P}\left(9.0 \mathrm{~kg} \mathrm{ha}^{-1}\right)$ and medium in $\mathrm{K}\left(160 \mathrm{~kg} \mathrm{ha}^{-1}\right)$. The experiment was conducted with 16 treatments combinations. The treatments consisted of different levels of NPK viz., 100 per cent, 75 per cent and 50 per cent RDF and different sources of nutrients viz., farmyard manure @ $12.5 \mathrm{tha}^{-1}$, fly ash @ $10 \mathrm{t} \mathrm{ha}^{-1}$ and humic acid @ $20 \mathrm{~kg} \mathrm{ha}^{-1}$ along with micronutrients boron @ $10 \mathrm{~kg} \mathrm{ha}^{-1}$ and zinc sulphate @ $25 \mathrm{~kg} \mathrm{ha}^{-1}$. The experiment was laid out in Randomized Block Design with three replications and tested with groundnut crop variety JL-11. The results reveled that the combined application of 100 per cent RDF + FYM significantly increased soil availability of nitrogen, phosphorus and potassium at all stages of crop growth in both soils. Among micronutrient treatments, 100 per cent $\mathrm{RDF}+\mathrm{ZnSO}_{4}+\mathrm{FYM}$ recorded maximum DTPA extractable zinc and 100 per cent $\mathrm{RDF}+\mathrm{Boron}+\mathrm{FYM}$ treatment registered maximum hot water soluble boron in both sandy clay loam and loamy sand soils at flowering, peg formation and harvest stages, respectively.

Key words : Major and micronutrients availability, Texturally different soils, Different growth stages, Ground nut crop

How to cite this article : Kamalakannan, P. and Ravichandran, M. (2014). Effect of organic and inorganic sources of nutrients on availability of major and micronutrients at different growth stages of groundnut (Arachis hypogaea $\mathrm{L}$.) in two texturally different soils, Tamil Nadu. Asian J. Soil Sci., 9(2): 234-239. 